\title{
\begin{tabular}{r|l} 
articles & THE POLITICalos
\end{tabular} SCANDAL AS NARRATIVE EXPERIENCE
}

Copyright (c) 2015 SBPjor / Associação Brasileira de Pesquisadores em Jornalismo
HÉLDER PRIOR

Universidade de Brasilia, Brazil

Universidade da Beira Interior, Portugal

\begin{abstract}
The work on the political scandal as a narrative experience seeks to address the relationship between the field of journalism and the narratological categories. We will try to establish a theoretical and conceptual framework of analysis of the mediapolitical scandal, considering the media role in the reconfiguration of the event into intelligible intrigues to the reader. From our point of view, the political scandals are complex narratives that develop in the press, and may be interpreted as "stories" that have a plot, major and minor episodes, characters, and meaning effects inherent to the "plastic work" of the medium in the moment of converting the phenomenon into a media experience. In the final part, we offer the reader a theoretical and conceptual schema of hermeneutic and pragmatic deconstruction of the media scandal, putting in evidence the significant value of scandal and the aesthetics component that it reveals.
\end{abstract}

Key words: Scandal. Narrativity. Media intrigues.

\section{O ESCÂNDALO POLÍTICO COMO EXPERIÊNCIA NARRATIVA}

RESUMO - O trabalho sobre o escândalo político como experiência narrativa procura abordar as relações entre o campo do jornalismo e os pressupostos da narratologia. Procuraremos estabelecer um quadro teórico e conceptual de análise dos escândalos político-mediáticos tendo em conta o papel dos meios de comunicação na reconfiguração do acontecimento em intrigas inteligíveis para o leitor. Na nossa perspectiva, os escândalos políticos são narrativas complexas que se desenvolvem na imprensa, podendo ser interpretados como "estórias" que têm um enredo, episódios principais e secundários, personagens, e efeitos de sentido inerentes ao "trabalho plástico" do medium no momento de converter o fenómeno numa experiência mediática. $\mathrm{Na}$ parte final, oferecemos ao leitor um esquema teórico e conceptual de desconstrução hermenêutica e pragmática do escândalo mediático, colocando em evidência o valor expressivo do escândalo e a componente estética que ele revela.

Palavras chave: Escândalo. Narratividade. Intrigas mediáticas. 


\section{EL ESCÁNDALO POLÍTICO COMO EXPERIENCIA NARRATIVA}

RESUMEN - El trabajo sobre el escándalo político como experiencia narrativa intenta abordar la relación entre el campo del periodismo y los presupuestos de la teoría de la narrativa. Así pues, buscamos establecer un marco teórico y conceptual para el análisis de los escándalos político teniendo en cuenta el papel de los medios de comunicación en la reconfiguración del evento en intrigas inteligibles para el lector. En nuestra opinión, los escándalos políticos son narrativas complejas que se desarrollan en la prensa, "historias" que tienen una parcela, episodios principales y secundarios, personajes y efectos de sentido inherente al "trabajo plástico" del medio en el momento de convertir el fenómeno en una experiencia mediática. En la parte final, ofrecemos al lector un marco teórico y conceptual de la hermenéutica y deconstrucción pragmática del escándalo de los medios de comunicación , destacando el valor expresivo del escándalo y el componente estético que revela.

Palabras clave: Escándalo. Narrativas. Intrigas mediáticas.

\section{THE MEDIA AND NARRATIVITY}

The narrative is inexorably linked to the history of mankind, to the history of the organization of human groups through the language use as a vector of communication. It is, therefore, present in all times, in all places and in all societies in a historical and transcultural form. It is only through narrativity that individuals can organize their daily experiences, their thoughts and ideas, the common sense shared in a temporal and causal order, attributing meanings to the world. Human action is organised through the construction of meanings that allow the subjects to make interpretations and representations of the world, experiencing the reality. In a sense, it is the understanding and interpretation of the world made by human beings in the process of relationship with things and with other subjects. It is an intersubjective, shared, relational and communicative attitude. The subjects recreate the real world through their own settings, through a certain intersubjectivity of materiality. In this perspective, the narrative appears linked to the Aristotelian idea of representation and re-creation of reality. According to Aristotle, there would be the reality of first order, the thing itself, and its representation, that is, a reality of second order crystallised in the symbolic representation of the absent referent. The mimesis would, therefore, be the representation of the world, the imitation of the perceptible world. 
So, the interpretation and configuration of media events is also done through reports and narratives that offer a certain unity and intelligibility to the social reality. The narrative is impregnated in the journalistic enunciation and at the various levels that compose the media. However, narrative conception as a mimetic representation of the outside world implies forgetting the enunciation and the communicative strategies inherent in the organization of reality operated by the media and the press narratives. That is why the perspective of the linguistic pragmatism understands narratives not only as just symbolic representations of the referent, but also and mainly as a language game inherent in each communication situation, each act and speech that more than merely representing the reality, institutes it, configures it, makes it understandable and intelligible. The narratives integrate and explain the future events of the world of life and, it must be said, the media events do not escape this logic of configuration and organization. The actions of the world of life are narrated and integrated through a conductor wire that reorders the events, their circumstances and consequences, while contributing to their understanding and explanation. As Ricoeur himself refers, to tell is simultaneously to explain: "To tell is a way to explain who we are, what we did and why we did it. The questions "who". "what", "how", "why" and others are already contained in the narrative intelligence" (Ricoeur, 1985. p. 35).

Indeed, we can say that the explanation of the world of life events is done through narratives that organize these events and that, at the same time, help to convert these events into something perceptible to the reader. Through explanatory resources, the narrative weaves the experience texture and establishes a causal relationship, a logical and orderly connection between fragmented events. It is about connecting, in the present, the past events in chronological order by establishing an antecedent and a consequent, but always in a temporary way, even because the events described in the present can be clarified, or reinterpreted. That is why "the narrative discourse is intrinsically incomplete" (Ricoeur, 1983, p. 205), because if the past is definitive, the future is always open.

At this point, the construction of media events also remains open to new reinterpretations and different versions. On the other hand, the narrative sentence varies according to the narrator's enunciative strategies, since the act of telling a story is always an intentional act, a variable report moulded or configured by the narrator's argumentative attitude, of the effects of the intended meaning, of the connections type that this one establishes, and from 
the point of view he adopts for sewing the narrative act. As pointed out by Searle, speech acts, whether they are locutionary, illocutionary or perlocutionary, they are always marked by the intentionality, by the intention of the speaker in producing, in receiver, understanding, signification (Searle, 2004, p. 45). In this way, the narrative enunciation is always marked by an argumentative and intentional attitude, by an enunciative strategy that aims to produce certain effects, whether they are factual or fictitious. (Motta, 2013. p. 38).

The narrative configuration of events is always marked by the intention to cover the narrative of an explanatory power obtained by the act of placing in relation the fragmented events, composing or sewing a unit or an intelligible whole. This is to "take together" (prendre ensemble) and to articulate the event with other events, configuring it. Thus, the configurante act consists in the articulation of actions, of the actors, the roles they perform, the circumstances of the action, its causes and consequences, lastly, the synthesis of heterogeneous and fragmented elements that are placed in an order, which are configured in a totality, in an intelligible composition. This intelligibility is guaranteed by the mise en intrigue, by the events connection, that structures the events in logic and that enables its signification. The action description is chained by semantic elements that work as a kind of "intersignification network" that integrates the heterogeneous elements of the action in a reordered narrative composition. It is the integration of heterogeneous elements in intrigues, through intentional discursive strategies, that enables the interpretation of the practical world of action. As Jean-Michel Adam underlines: "the narrative activity combines a chronological order and a configured order", a semantic configuration (Adam, 1984. p. 17).

However, it should be noted that the narrative discourses of the press are neither naive nor constructed at random. On the contrary, the narrative communication structures itself regarding the pragmatic contexts that produce, consciously or unconsciously, certain effects in the receiver. According to a certain pretension, the narrator organizes and structures the discourse in order to be interpreted in the desired way, taking into account its intentions and its objectives. In this sense, the narratives are more than mere representations of reality. They are, above all, discursive devices of configuration and institution of reality in pragmatic contexts and always on the basis of a certain point of view. The narrative discourse is coated with an illocutionary and perlocutionary force because there is always a certain communicative intention to achieve that, by its turn, aims to obtain certain effects in the 
interlocutors. The narrative communication implies, therefore, syntactic and pragmatic skills and that is why the narrative constructions, whether factual or fictitious, are constructions of meaning, "mental representations linguistically organized" (Motta, 2013, p. 83).

Consequently, the media configuration of public events is impregnated by narrativity, because the media carry out reconstitutions of public events in the form of intrigues, representing the factual reality and producing, simultaneously, cultural, political and ideological senses. As the knowledge that we have of the world goes far beyond the direct experience within the reach of our eyes, being, in a way, as a "second hand" knowledge, the media "represent the main mean of contact with the environment that is not seen" (Lippmann, 2003, p. 261), as Walter Lippmann pointed out in his revealing book about The Public Opinion, published in 1922. In this context, the media events interpretation generates, mainly, through reports and narratives which give to these events not only its existence in the public mind, but also a certain intelligible unity of meaning that allows its reconfiguration and interpretation by the subjects. As the sociologist Gaye Tuchman said, possibly the first author to call the news of "stories", in the description process of an event, the news define and shape this event, offering to the reader a "selective abstraction intentionally consistent". In Tuchman's words:

The informative reports not only give the occurrences its existence as public events, but also give them a certain character, to the extent that they help shaping the public definition of events, attributing them in a selective way details or specific peculiarities (Tuchman, 2003, p. 97).

In another essay, entitled Telling Stories (1976), the author states that "saying that the news information is a report is neither to debase the news nor to accuse it of being fictitious. On the contrary, it warns us that the news, as all public documents, is a selective and constructed reality with its own internal validity" (1976, p. 262). Approximately twelve years later, Elizabeth Bird and Robert Dardenne added that "the news are part of an old cultural practice - the narration and stories account -, which seems to be universal" (Bird; Dardenne, 1988, p. 265). In this perspective, the news information (news accounts) is culturally constructed narrations that give meanings to reality and where the contingent event is reconfigured in an intrigue that has a narrative course and a conductor wire. Seeking to reawaken the real effect, bringing closer their reports to the reality and ensuring the news 
objectivity, creating a certain illusion of reality, the reports which are transmitted by the press exploit preferentially the factual through an objective language which meets the cognitive contract of truthfulness that the narrator/journalist establishes with the interlocutor/reader.

However, as the version on reality is not the reality in itself, the fact in itself, but only one version operated by the linguistic reconstruction of the event, by its crystallization, the journalistic enunciation is full of reporting strategies that go far beyond the literal, referential or factual report about the event. We refer to the construction of meanings present in the journalistic communication, construction that aims to awaken not only the effect of the intended real, but also cultural, political, social or ideological meanings.

According to the adopted point of view, the narrator uses certain enunciated tricks that allow him to organize or to order the actions and the sequences, that is, the episodic and temporal dimension of the narrative, to position and to characterize the characters or appeal to the seductive and aesthetic dimension of journalistic language to involve the interlocutors and capture their attention. And such positions are not only factual or referential, but they also are, artificial or made of facts. They allow to characterize the narrator as the enunciation agent, as a speech actor responsible for selecting, organizing and configuring intentionally the narrative act generating, at the reception moment, certain effects of meaning in the interlocutors. At this point, the journalist assumes the narrative voice; he is the speaker responsible for the process of utterance and by the communication exchanges established in the course of a vertical communication. He assumes himself as the enunciator subject responsible for the utterance mediation, by the facts presentation in accordance with the angle that he chooses, by positioning the characters and by stimulating a particular state of mind in the audience before the report.

It is up to the journalist "to furnish" the world of action, that is, to situate the facts (What), a place (Where?) and a time (When?), at the same time that he endows characters (Who?) with a certain number of characteristics. First of all, to narrate a story it is necessary "to build a world", "to furnish" the world with action "down to the finest details" (Cf. Adam; Revaz, 1997, p. 34). Nevertheless, the language that enables "to furnish" the world always presents an ideological status, because the journalist's speech acts can only be fully understood considering the place (practical, ideological, theoretical) where he speaks, that is, the language topic status. "Whenever the place from where we talk institutionalises itself and what we speak in the name of acquires a 
certain consistency, we are in front of a "catchy" language, and that assumes the status of ideological system" (Barthes, 1973, p. 21).

This is what Roland Barthes called the "war of languages" as the language always comes from some place, is "top warrior" that needs of his shadow and this shadow is, according to Barthes himself, "a little ideology, a little representation, a little subject" (Barthes, 1973, p. 72). It is true that the journalistic text seeks to give the idea that there is no mediation between the event converted into textual object and that event receiver that experiences the object or the textual artefact.

However, the journalistic narratives, particularly those which give account of policy agonistic events, are full of the narrator's strategies, often masked in the journalistic language, carrying the reader to the space and time of the events, awakening reality effects, but that also allow the imagery reconstruction and a certain aesthetic experience inherent to this reconstruction. Thus, the experience of media-political scandal, which particularly interests us in this work, is quite elucidating, not escaping the narrative logic of the media "machine". The narrative process generates in the journalistic enunciation and the dramaturgy inherent in the political scandal triggers the expressive and pragmatic modalities of the symbolic mediation devices, either covertly, whether in a more or less evident, more or less visible form. On the other hand, and given that the field of the media is part of the entertainment industry, the journalistic enunciation ends up by producing a multitude of dramatic narratives on politics events, particularly on disruptive events.

\section{THE POLITICAL SCANDAL}

Before beginning our perspective on the political scandal as a diegetic experience, it is necessary to make some remarks about the concept and its origin. Thus, and according to the meaning which can be drawn from the Septuaginta, the Greek translation of the Hebrew Old Testament the word skandalon was used to indicate an "obstacle", "an error falling moment for the weak", or "an occasion of stumbling". In theological meaning, skandalon refers, therefore, to a sinful behaviour, a "stumbling stone" that can lead someone to the fall, to the ruin. According to Saint Mark, the scandal is an outrage resulting from an occasion of sin that deserves a "divine punishment". It is "an indignation produced by bad examples", as it can be read in the Grande Dicionário da Língua Portuguesa. However, with the emergence of Romance variations during 
the Middle Age, as the words scandalum, "escandre", escandalho, and escandêlo ${ }^{1}$, scandalo and escándalo, the religious meaning ended up eventually by being progressively mitigated and the phenomenon has acquired a meaning far beyond the Judaeo-Christian tradition. Therefore, from a sociological point of view, the scandal can be interpreted as a societal provocation, as the derogation of values socially shared by individuals.

In a classic text, originally published in 1954, Eric of Dampierre considers that the scandal involves the "existence of values shared by a particular social group and the existence, or the possibility of the existence of an audience" (Dampierre, 1954, p. 330). In accordance with the reading that can be surmised from Dampierre's text, the scandal involves the transgression of certain social, political, religious or moral values or codes, and, on the other hand, the transgression publicizing and the existence of a public that recognizes it, that feels offended by it and that publicly expresses its indignation or disapproval in the public sphere.

This way, the scandal implies the existence of a transgression that, when it is known by individuals who are not directly involved in this transgression, when it is publicised, it creates feelings of disapproval, it generates the manifestation a certain accusatory and simultaneously moralising speech. It is for this reason that from the moment we witnessed the publicizing of a transgression, the scandal associates illocutionary and perlocutionary values, to the extent that it happens when it is enunciated and by the fact that it is enunciated, awakening effects of disapproval or widespread indignation. In a way, it is about speech turned into action and an action turned into speech that highlights a certain performative character. Through the movement of speech acts, the "occasion of stumbling" becomes public, that is, it offers itself to the meanings and raises a specific reaction. Besides, as Molière stresses: "it is the public scandal that offends; to sin in secret is not to sin at all" (Cf. Apostolides; Williams, 2004, p. 3).

In this sense and as the playwright himself recognizes, without the transgression publicizing, there simply cannot be a scandal. That is why that authors as Apostolides and Williams suggest that "the scandal must be understood as the transgression publicizing of a social norm" (2004, p. 3), emphasizing the visibility and advertising value to understand the phenomenon. So, we know that the public sphere today is guided by the visibility and transparency principles claimed by the Enlightenment philosophy that has incorporated the publicity principle in the democratic political theory, in opposition to the secret /havens 
and arcane rei publicae characteristic of the traditional doctrine of the State reason. "Everything must be shown, exposed and enlightened", declare Diderot and D'Alembert in Encyclopédie (Starobinsky, 1979, p. 304). And, as it is known, it was the illustration spirit that allowed the establishment of a kind of tribune, the press, according to which "it is difficult to hide anything and it is impossible to diminish", as stressed by the Marquis of Condorcet, considered as the last of the illuminated (Condorcet, 1970, p. 117).

Therefore, the principles of transparency and visibility in the political field erected as a mainstay of the liberal democracies, as something "good and fair", opposed to the closed and secret policy of cabinet specific of the monarchical absolutism (Cf. Schmitt, 2008, p. 80). Therefore, if the scandal has become a prominent feature of the social and political life today, such cannot be dissociated from the demand for the publication principle of the government acts. That is why that authors as Markovits and Silverstein consider that scandals can only emerge in liberal democracies (1988, p. 5), precisely because these grants extreme importance to the visibility of the political power given, in large part, by institutional or parliamentary mechanisms of control, and by politics environment monitoring done by free and independent media. As Theodore Lowi assures "since the public exposure is a crucial element of the political scandal, we can say, as if it was a theorem, that the society will have little or no scandals if there is no of institutionalised means of exposure" (Lowi, 1988, p. 10).

On the other hand, we know that the media are always ready to "disqualify" or discredit the political sphere, pointing out their possible dysfunctions and denouncing their abuses or deviations before the public opinion. Actually, the watchdog role still remains as one of the ethos characteristic values of the journalistic profession, but if the supervising and vigilant approach of the press before the political sphere helps to explain, in part, the profusion of political scandals, we must not forget that the scandal "adds drama" to journalistic stories and therefore it attracts the public attention. "The scandal attracts the attention, it offers readers and audiences to the media and therefore it helps them to achieve economic gains" (Dagnes, 2011 , pp. 4-5).

Thus, and once that political scandal does not happen spontaneously, it is essential that the transgression of the prescriptive procedures that governing the exercise of political power gets the attention of media organizations that, in order to convert the phenomenon into something that can be understood by the public, configure the 
event in a media narrative that gains plots and subplots as the scandal develops and unfolds. By converting itself in a media event, the political scandal acquires a configuration marked by the particularities of the media forms of communication. As Thompson suggests: "The scandal develops, literally, in the media; and the professional activities and the media organisations play a crucial role with its practices and specific working rhythms," (Thompson, 2000, p. 75). Many times, the political scandal is a complex event that unfolds on primary and secondary plots. The research and publication of the initial transgressions that are at the origin of the outbreak of a scandal can lead to revelation and consequent media exploitation of "second order transgressions" which, in some cases, keep a tangential or superficial relationship with initial transgressions, giving origin to sub-scandals or larger scandals that can even eclipse, especially from the media point of view, the "first order" transgressions (Thompson, 2000, p. 25).

However, our view is that, in order to organize the inherent complexity of the phenomenon, the communicational devices of symbolic mediation insert the scandal in the order of discursive facts, selecting, cutting out, framing, shaping and disseminating the events that are the basis of a phenomenon that bursts in the public sphere. It is at this point that the linguistic devices specific of the media field operate an event reconfiguration or re-figuration, appropriating the event to convert it into a media object that can be, independently of its complexity, easily interpreted by the reader at the moment of its reception.

\section{THE NARRATIVE EXPERIENCE OF THE MEDIA SCANDAL}

Using linguistic resources or the strategies of /reference strategies, the medium seeks to awaken in the receiver the real effect to convince the reader that what is narrated is related to the reality, it finds a relationship with the referent. The contextualization of the hypothetical transgressions, the identification of the characters involved in those transgressions and in their publication or denunciation, the events temporal specification, often using chronological infographics that carry the reader to the time of the events, the places identification, or the use of citations or testimonies, are narrative strategies that, at the same time, allow to rebuild an intrinsically complex event, and also confer veracity to the narrated facts.

However, and since the political scandal is, in itself, an ecstatic 
event that triggers the dramatic devices, adapting easily to the media production machine of aesthetic effects that aim to capture and hold the public attention, the journalistic language often makes use of production strategies of meaning effects that invite the reader to subjective interpretations and that, on the other hand, arouse interest and curiosity in following a disruptive plot that changes the normality flow, that breaks with homeostasis and with the balance of the political system and, why not say it, its own media system and its routines. In the specific case of our study subject, the aesthetic or poetic effects arouse, especially, feelings of indignation, wonder, perplexity, surprise and shock, introspection or, in the case of the transgressions are punished and normality is restored, purification or catharsis.

It is at this point that an author as Gianni Vattimo considers that the media make possible a kind of "fable made world", contributing to the explosion and multiplication of alternative and subjective visions about social events. Let us look at Vattimo's wording in the work Transparent Society:

\begin{abstract}
What sense would have the freedom of information, or even just the existence of multiple radio and television channels, in a world where the standard was the exact reproduction of reality, the perfect objectivity, the total identification of the map with the territory? (Vattimo, 1989:12).
\end{abstract}

This is what the author calls of mass media fantasy world, a world where the information appears often as a "story", as an episodic "novel" temporally organized, with its characters, with its moments of conflict in the plot, with stylistic or expressive resources that invite the reader to subjective interpretations, but also that tie him to the story following the dramatic moments that humanise the events and that arouse, in many cases, an ethical and moral background.

Indeed, the press narratives do not only send readers to the real or factual world, but they invite him to subjective interpretations, to a cognitive and emotional experience that frees the subject from the world of life (Motta, 2013, p. 216). By mise en récit (Lits, 2008, p. 35), the media make us discover the stories of the world using narrative and linguistic operations structures that form the selected reality and that provide certain views or interpretations of these events. In this context where the mass media assumes itself as a narrative device, such as "narrative machinery", as Adriano Duarte Rodrigues refers (1988), the political scandal displays a communicative dynamic that is gaining settings and meanings as the action, the plot, the episodes, 
the characters, and the meaning effects inherent in the plastic work of the medium, recompose and rewrite themselves in the media field. The scandal acquires a certain narrative framework ${ }^{2}$ based on the textual organization of events, in its fragmentation into major and minor episodes, on the individualization or personalization of the narrative schema through characters identification and construction that perform certain functions in the plot $^{3}$ and help to structure the diegesis (Propp, 1984; Todorov, 1970), in the definition of the events temporality and in a certain aesthetic or poetic composition of the intrigue inherent in the journalist's stylistic ability at the moment of sewing the narrative act.

It is in this perspective that we consider that the media organization of the elements constituting the political scandal allows to define its reconfiguration as a diegetic experience, as a plot that, due to the action of the journalist's narrative, makes it possible for the reader not only to monitor the story, but also to experiment it . The representation forms of language make possible the phenomenon representation, its narration, organization and explanation. The media reconfiguration of the event determines the perception modes of the scandal, the perception modes influenced by the cunnings of the narrative enunciation used by journalist at the time of the phenomenon recovery, but also by subjective apprehension held by the subjects at the time of its cognitive reception and appropriation. The description of the hypothetical transgressions that are at the origin of the outbreak of a particular scandal, the definition of the temporality of events that, according to Paul Ricouer, appears linked to the narrativity itself, since temporality has access to language through narrativity and narrativity is "a linguistic structure" that has temporality as referent (Ricoeur, 1999, p. 183), the sequencing of a complex phenomenon in episodes, or the construction of the narrative players, are elements that allow the attribution of meaning to reality rebuilt in a recomposition process of resources that give life to the political scandal narrative (Pastor, 2013, pp. 172-173).

On the other hand, in the narrative experience of scandal, it is verified what Claude Bremond (1971) calls the dichotomy between destabilization and stabilization, between a state which degrades and an action to improve this state, between degradation of values and attempts of purification, moralizing or restoring the order infringed in the meantime. The scandals that put into question the norms and values of societal or political order are often moments of reflection and debate, moments when society faces its weaknesses and in which particularly the media claim for strengthening norms and conventions meanwhile 
broken ${ }^{4}$. Transgressions are revealed, offenders are identified and, in some cases, punished, in some kind of ritual that ultimately contribute to the purification of the political institutions and for the recovery of public morality. It is a polarized tension involving individuals who find themselves at the epicentre of the scandal, political parties, journalists, differentiated elites and, of course, the reaction of the public opinion.

\section{INTERPRETATIVE CONSIDERATIONS ABOUT THE NARRATIVE EXPERIENCE OF SCANDAL}

From the stated considerations, we intend to suggest that in the process of hermeneutic deconstruction of media scandal it is possible to think about the construction of stories, plots and characters resulting from the logic, the languages and the features of the media narrative machine. From our perspective, the media scandal should be interpreted as an open process, as a hermeneutic game of meanings that acquires a certain expressive value, reconfiguring itself in linguistic devices of information by elements of "selective reality", as it was called by Tuchman (1999, p. 262), and through the technical chain of media discourse strategies. The "mass media fantasy" world combines the journalistic techniques with the fictional universe techniques, eventually producing narratives and dramatic structures that generate through an enunciative process, mainly as far as the adversarial events in politics are concerned. Therefore, the political scandal, for being an event eminently dramatic and extemporaneous, it assumes a communicative dynamic that, according to our analysis, promotes its reconfiguration as media intrigue. Indeed, and in accordance with the theoretical and conceptual schema that we have tried to suggest, it is possible to identify some significant features of the political scandals that can be quite useful for analysts who are interested in the study of this kind of narrative.

1. Publicising and denunciation: the scandal claims publicity and the logic of the media field, as we have seen, the function of transparency. The field of journalism contributes to reduce the scope of secrecy and discretion of the political sphere, denouncing its abuse to the public opinion. Without the publicity and denunciation of the transgressions, which generate disapproval feelings in the public opinion, the scandal as narrative and newsworthy event could not break through. 
2. Narrativity: As we have pointed out, the narrative process generates itself in the journalistic enunciation and, as we know, the political field offers the media a multiplicity of possible narratives. This way, we stress that the political scandal activates the expressive and aesthetic modes of the symbolic mediation systems and, as the media field is part of the entertainment industry, the journalistic enunciation turns out to produce "dramatic narratives" about political events. Through narrative schemas, journalistic writing converts the event into something describable and intelligible where speech acts lead the reader to certain real effects and meaning effects.

3. Dramatization: As it is known, the media narrative machine has a dramatic demand, the higher the possibility of dramatization of an event, the greater the possibility of that event to be publicized and, therefore, to be a part of the imagination of the reader/spectator. We have viewed the conflict framing through its dramatic structure, to the plot organisation, the event contextualization, the transgression highlight, the deviation emphasis, a certain accusing and also moralising speech. Perhaps it is appropriate to point out that the scandal becomes a representation, with plots and subplots, with major and minor characters, where a recreational and aesthetic dimension is also visible, allowing to enjoy the visual event, which allows spectatio.

4. Personalisation: Any narrative needs characters and the media scandal has, necessarily, its dramatis personae. The characters carry out certain functions in the plot, functions that are important in the action progression, as Propp stressed (1984). In the case of media scandal, it is predictable to view a division between offenders and informers, between major and minor characters, protagonists or antagonists, purifier heroes and transgressor villains, individual or collective characters. We have seen the construction of the characters' nature through the role that these play in intrigue. As Tzvetan Todorov refers, the characters cannot exist outside of the action and, on the other hand, there can be no action without characters (Todorov, 1970, p. 120).

5. Temporality: As we have already mentioned, there is a reciprocal relationship between narrativity and temporality. Temporality is related to the development of intrigue, since to tell a story you need to temporally arrange the events. It is temporality that enables the unfolding of the intrigue in its most significant moments, allowing placing the 
reader at the time of the events and, at the same time, helps the narrator to arrange the enunciated time. As the transgressions that are at the base of scandals past actions refer to past actions, the expressive feature of temporality allows place the events in the present time.

6. Seriality: Most of the media scandals are complex narratives that are being fed as new data or elements are unveiled. The media scandal unfolds, literally, in episodes, in primary and secondary plots that ultimately stimulate the public curiosity in following a disruptive plot. It is the seriality of the scandal that feeds the narrative machine of the media and that ensures the presence of conflict in the spectator's everyday life.

7. Intertextuality and circularity of information: Pierre Bourdieu referred that information is a kind of "game of mirrors" (Bourdieu, 1997, p. 19) where the competition effect turns out to homogenise the media productions. By converting itself into a media event, the political scandal becomes amplified and present in most mass media, which contributes to the multiplication and proliferation of media narratives about the same event.

8. Artefactuality: the media culture is a manufactured reality and the scandal does not escape the makeup logic of the media field. The world reality of life is mediated by communicational schemes, symbolic schemes that select, frame, shape and, in some cases, end up deforming reality itself. The effects of the media communication convert the reality in a second-hand experience and, as Derrida pointed out (1996, p. 11), through a range of "hierarchical", "selective" and "artificial" procedures, the texture of the journalistic discourse is often shaped and deformed through news narratives that convert the fictional in news and, consequently, in reality.

The work on the political scandal as a narrative experience leaves, thus, an open project. Our main objective was to assemble a theoretical and conceptual schema that allows understanding the reason why the scandals constitute themselves as contemporary media narratives where it is possible to identify certain expressive capabilities inherent in journalistic enunciation.

*This paper was translated by Isabel Serra. 


\section{REFERENCES}

AA.VV. Dicionário da Língua Portuguesa Contemporânea, Lisboa: Calouste Gulbenkien, 2011.

ADAM, J.M, Le Récit, Paris: Presses Universitaires de France, 1984.

ADAM, J-M; Revaz, F. A Análise da Narrativa, Lisboa: Gradiva, 1997.

APOSTOLIDES, P: WILLIAMS, J.A, Public Affairs, Politics in the Age of Sex Scandals, London: Duke University Press, 2004.

ARISTÓTELES. Poética, Lisboa: Imprensa Nacional Casa da Moeda, 2005.

BARTHES, R. O Prazer do Texto, Lisboa: Edições 70, 1973.

BIRD, E. DARDENNE, R. "Mito, Registo e Estórias: explorando as qualidades narrativas das notícias", in TRAQUINA, N. (Org), Jornalismo, Questões, Teorias e "Estórias", Lisboa: Veja, 1999.

BREMOND, C. A Lógica dos Possíveis Narrativos, In BARTHES, R. Análise estrutural da narrativa, Pétropolis: Vozes, 1971.

BOURDIEU, P. Sobre a Televisão, Oeiras: Celta Editora, 1997.

CONDORCET. Esquisse D'un Tableau Historique des Progrés de L’Esprit Humain, Paris: J Vrin, 1970.

DAGNES, A (Org). Sex Scandals in American Politics: A Multidisciplinary Approach to the Construction and Aftermath of Contemporary Political Sex Scandals, New York, Continuum Internation Publishing Group, 2011.

DAMPIERRE, E, de. “Thémes por l'étude du scandale”, in Annales, Économies, Sociétés, Civilisations, 9e année, № 3, 1954.

DERRIDA, J; STIEGLER, B. Échographies de la télévision, Paris: Galilée, 1996.

KANT, I. A Paz Perpétua e outros Opúsculos, Lisboa: Edições 70, 2004.

LAZARSFELD, P; MERTON, R. "Mass Communication, Popular Taste and Organized Social Action", in BRYSON, L. The Communication of Ideas, New York: Harper and Row, 1948.

LIPPMANN, W. La Opinión Pública, Madrid:Editorial C. de Langre, s/d.

LITS, M. Du Récit au récit médiatique, Bruxelle: De Boeck, 2008.

LOWI, T. "Prefácio", in MARKOVITS, A; SILVERSTEIN, M. (org), The Politics of Scandal: Power and Processes in Liberal Democracies, New York: Holmes\&Meier Publishers, 1988.

MARKOVITS, A; SILVERSTEIN, M. (org), The Politics of Scandal: Power 
and Processes in Liberal Democracies, New York: Holmes\&Meier Publishers, 1988.

MOTTA, L.G, "Análise Pragmática da narrativa jornalística", in LAGO, C. ; BENETTI, M. Metodologia da pesquisa em jornalismo, Petropólis: Vozes.

MOTTA, L.G, Análise Crítica da Narrativa, Brasília: Editora UNB, 2013.

PROPP, V. Morfologia do Conto Maravilhoso, Rio de Janeiro: Forense, 1984.

PRIOR, H. GUAZINA, L. ARAÚJO, B. Corrupção e Escândalo Político: o enquadramento do escândalos Face Oculta e Mensalão na imprensa portuguesa e brasileira, in Revista Media \& Jornalismo, $\mathrm{N}^{\circ} 26$, pp. 167-185, disponível em: http://www.cimj.org/revista/26/1 1 prioretal.pdf

PRIOR, H. Esfera Pública e Escândalo: o secreto no âmbito público, Tese de Doutoramento, Covilhã: Universidade da Beira Interior, 2013.

RICOEUR, P. Temps et Récit I, Paris: Le Seuil, 1983.

RICOUER, P. Temps et récit III, Le temps raconté, Paris: Le Seuil, 1985.

RICOEUR, P. Historia y Narratividad, Barcelona: Paidós, 1999.

RODRIGUES, A.D. O campo dos Media, Discursividade, Narratividade, Máquinas, Lisboa: Veja, 1984.

STAROBINSKY, J. “L'arbre du savoir et ses metamorphoses", in Encyclopédie de Diderot et D’Alembert, Essais et Notes, Milão: Franco Maria Rici, 1979.

SCHMITT, C. Los Fundamentos histórico-espirituales del parlamentarismo en su situación actual, Madrid: Tecnos, 2008.

SEARLE, J.R, The Philosophy of language, Oxford: Oxford University Press, 2004.

TODOROV, T. "Las categorias del relato literário", in Analisis Estructural del Relato, Barcelona: Ediciones Buenos Aires, 1982.

TODOROV, T. As estruturas narrativas, São Paulo: Perspectiva, 1970.

THOMPSON, J. B. Political Scandal, power and visibility in the media age, Cambridge: Polity Press, 2000.

TUCHMAN, G. "Contando estórias", in TRAQUINA, N. (Org), Jornalismo, Questões, Teorias e “Estórias”, Lisboa: Veja, 1999.

TUCHMAN, G. "As notícias como uma realidade construída", in ESTEVES, J.P. Comunicação e Sociedade, Lisboa: Livros Horizonte, 2002.

VATTIMO, G. A Sociedade Transparente, Lisboa: Relógio D’água, 1992. 


\section{NOTES}

1 In the General Chronicle of Spain there are records of the use of the Portuguese words "escandalho" and "escandêlo", in the $13^{\text {th }}$ and $15^{\text {th }}$ Century, respectively. Cf. Dicionário Etimológico da Língua Portuguesa, Lisboa, Livros Horizonte, 1995, p. 439.

2 According to background studies, the journalist uses strategies to put in order the chaos of everyday life, making certain choices in the face of the raw matter, before events that need to be ordered and configured to acquire intelligibility.. For further study of the political scandal under the optics background vide Prior, $\mathrm{H}$, Guazina, L, Araújo, Bruno, Corrupção e Escândalo Político: o enquadramento dos escândos Face Oculta e Mensalão na imprensa portuguesa e brasileira, in Revista Media \& Jornalismo, 26, disponível em: http://www.cimj.org/revista/26/1 1 prioretal.pdf.

3 Regarding the identification and constructions of the scandal character, see the magazine edition Veja of the $10^{\text {th }}$ September 2014 entitled "O Delator fala", in an allusion to Paulo Roberto Costa, Petrobrás ex-director. In September 23 $3^{\text {rd }}, 1992$ edition it is also visible as PC Farias is blamed by the journalistic enunciation on the subject entitled "A voz do vilão", about the corruption scandal involving the then-President Fernando Collor de Mello

4 At this point, Paul Lazarsfeld and Robert Merton's words acquire particular relevance when they state that mass media serve to confirm the social norms, denouncing their deviations to the public opinion.Cf. Paul Lazarsfeld; Robert Merton, "Mass Communication, Popular Taste and Organized Social Action", in Lyman Bryson, The Communication of Ideas, New York, Harpe rand Row, pp. 102-103.

Hélder Prior is posdoctoral researcher at University of Brasília. PhD ("European Doctor") 2013 - Communication Sciences from the University of Beira Interior (Portugal). Integrated PhD - Online Communication Lab (LabCom) of University of Beira Interior; Research collaborator of the Observatorio Iberoamericano de la Comunicación of the Autonomous University of Barcelona. 